\title{
Assessment of Coronavirus Pandemic Effect on Air Quality in Cyprus
}

\author{
Sedef Cakir ${ }^{1 *}$, Princewill Mbachu ${ }^{2}$ \\ $\mathbf{1}^{*}$ Cyprus International University, Faculty of Engineering, Department of Environmental Engineering, Mersin 10 Turkey, (ORCID: 0000-0003-3049-2635), \\ scakir@ciu.edu.tr \\ ${ }^{2}$ Cyprus International University, Institute of Graduate Studies and Research, Environmental Science Program, Mersin 10 Turkey, (ORCID: 0000-0002-7172-313X), \\ mbachuprincewill@yahoo.com
}

(First received 20 December 2021 and in final form 25 January 2022)

(DOI: 10.31590/ejosat.1038697)

ATIF/REFERENCE: Cakir, S., Mbachu, P., (2022). Assessment of Coronavirus Pandemic Effect on Air Quality in Cyprus. European Journal of Science and Technology, (33), 207-212.

\begin{abstract}
The emergence of the infectious virus known as Coronavirus (COVID-19) in the Chinese city of Wuhan at the end of 2019 not only affected the world politically, socially and, economically but also had an impact on the environmental issues in most of the countries. During the curfew period in many countries due to the coronavirus, it was hypothesized that there would be a decrease in the level of air pollution due to the significant decrease in anthropogenic activities. The aim of the study is to analyze the level of air pollution for specific pollutants (Particulate matter, $\mathrm{NO}_{2}$, Ozone) in Cyprus within the period from January 2020 to June 2020 and to compare the obtained results with the air quality data for the same period in 2019. This period was selected to cover the time frames before lockdown, during lockdown and partial lockdown implemented in Cyprus. In order to make a comparative analysis with 2019 , monthly mean values of the pollutants and mean values of three phases were obtained using the satellite data. Differences were presented as percentages and t-test was applied to determine if these differences were significant. Significant reduction in $\mathrm{NO}_{2}$ values was detected during the lockdown and partial lockdown periods compared to the values obtained at the same periods of 2019, while AOD and Ozone values did not decrease significantly during the lockdown period.
\end{abstract}

Keywords: COVID-19, Lockdown, Air Quality, AOD, $\mathrm{NO}_{2}$, t-test.

\section{Koronavirüs Pandemisinin Kıbrıs'taki Hava Kalitesine Etkisinin İncelenmesi}

$\ddot{O} \mathbf{z}$

2019'un sonunda Çin'in Wuhan şehrinde Coronavirus (COVID-19) olarak bilinen bulaşıcı virüsün ortaya çıkması, dünyayı yalnızca politik, sosyal ve ekonomik olarak etkilemekle kalmadı, aynı zamanda çoğu ülkenin çevresel konularını da etkiledi. Koronavirüs nedeniyle birçok ülkede alınan sokağa çıkma yasağı döneminde, antropojenik faaliyetlerin önemli derecede azalması nedeniyle hava kirliliği seviyesinde bir azalma olacağı düşünülmekteydi. Bu çalışma, Ocak 2020'den Haziran 2020'ye kadar olan dönemde Kıbrıs'taki hava kirliliği seviyesini bazı kirleticiler (Partikül madde, $\mathrm{NO}_{2}$, Ozon) için analiz etmeyi ve çıkan sonuçların 2019 yılı aynı dönemindeki hava kalitesi değerleri ile karşılaştırmayı amaçlamaktadır. Bu dönem, Kıbrıs’taki sokağa çıkma yasağı öncesi, sokağa çıkma yasağı ve kısmi sokağa çıkma yasağı periyotlarını kapsayacak şekilde seçilmiştir. 2019 yılı ile karşılaştırmalı bir analiz yapmak için uydu verileri kullanılarak kirleticilerin aylık ortalama değerleri ve üç periyottaki ortalama değerler elde edilmiştir. Farklar yüzde olarak verilmiş ve bu farkların anlamlı olup olmadığını belirlemek için t-testi uygulanmıştır. Sokağa çıkma yasağı ve kısmi sokağa çıkma yasağı dönemlerinde $\mathrm{NO}_{2}$ değerlerinde 2019 yılının aynı dönemlerine göre anlamlı bir düşüş olduğu ancak AOD ve Ozon değerlerinde anlamlı bir farklılık olmadığ 1 tespit edilmiştir.

Anahtar Kelimeler: COVID-10, Sokağa çıkma yasağı, Hava kalitesi, AOD, $\mathrm{NO}_{2}$, t-testi.

\footnotetext{
* Corresponding Author:scakir@,ciu.edu.tr
} 


\section{Introduction}

Air pollution which is the introduction of chemicals, particulate matter (PM), or biological materials that cause harm to humans or other living organisms, or cause damage to the natural environment or built environment, into the atmosphere (Agbaire and Esiefarienrhe, 2009) is a global issue as it affects both the developing and developed countries. Problems with air quality are more persistent in highly populated and industrialized areas with poor air quality control management strategies (Rai et al., 2013). Pollution stress can alter plant and animal lives, human health situations and the environment as a whole due to the fact that various concentrations of different air pollutants can alter the atmospheric and environmental balance. It has been reported by the Environment, Rural and Marine Resources of the Spanish Ministry that air pollution causes more death in a year than road accidents (Marcos, 2011).

The coronavirus is one of the most recent emerging species of viruses that has been posing a great challenge to many people around the world as scientists are doing everything possible to prevent its spread and also looking for possible treatment methods and preventive vaccines (Briz-Redón et al., 2021). Due to the speed that the coronavirus spread around the world and also its severe health impacts on human lives, it has been termed a global pandemic (Wang et al., 2020).

Some measures were taken by the authorities of the countries across the world to prevent the spread of the virus from one person to another and from one country to another. The lockdown was the major policy measure that was implemented as an emergency method to slow the rate of COVID-19 transmission. Some of the other measures included social lockdown thereby preventing public gatherings of any type hence everyone was kept at home (Das et al., 2020; Patel et al., 2020). All types of public and private transportation have been stopped during the coronavirus lockdown (Tosepu et al., 2020). Factories were shut down while malls, cinema theatres, and streets were deserted and almost all activities were halted worldwide. Education of all forms became online as no face-to-face studies were permitted (Bukhari and Jameel, 2020).

The virus has not only affected the world politically, socially and economically but also had impacts on the environmental components of most cities around the world. The lockdown measures implemented in response to the COVID-19 pandemic is thought to be a general blessing to the environment globally (Mahato et al., 2020) though some little disparities were observed in a few countries. For example, it was observed that there was a considerable general decrease in the level of $\mathrm{NO}_{2}$ in some countries like China (Zhao et al., 2019; Wang and $\mathrm{Su}, 2020$ ), the USA (Berman and Ebisu, 2020), India (Mahato et al., 2020), Brazil (Nakada and Urban, 2020), Kazakhstan (Kerimray et al., 2020), Spain, France, Italy (Gautam, 2020) and Samsun, Turkey (Efe, 2021). Şahin (2020) showed that there was a significant reduction in $\mathrm{PM}_{10}$ values in Istanbul during the COVID-19 compared to the values obtained before COVID-19. Conversely, an increase in the ozone levels was noticed during this same lockdown period in some European countries (Sicard et al., 2020), Latin American countries (Nakada and Urban, 2020; Siciliano et al., 2020), and Asian countries (Kerimray et al., 2020). The increase in $\mathrm{O}_{3}$ levels had been associated with a decrease in NO as there was a little breakdown of $\mathrm{O}_{3}$ by $\mathrm{NO}$ (Nakada and Urban, 2020)

e-ISSN: 2148-2683
It was reported that the concentrations of black carbon (BC) and $\mathrm{NO}_{2}$ were reduced to half of their initial values while PM10 concentration experienced about one-third reduction in the city of Barcelona due to the lockdown (Tobías et al., 2020). It was also claimed that the reduced anthropogenic activities and hence emissions during the lockdown period were not good enough to stop serious air pollution occurrence in 10 major cities in China (Wang et al., 2020).

Dantas et al., 2020 investigated the impact of the lockdown on the air quality in the city of Rio de Janeiro, Brazil. The concentration of the pollutants $\mathrm{PM}, \mathrm{CO}, \mathrm{NO}_{2}$, and $\mathrm{O}_{3}$ were measured during the period of lockdown (23 $3^{\text {rd }}$ March to $16^{\text {th }}$ April, 2020) and the values were compared to the concentration of the same pollutants obtained in the same period in $2019\left(23^{\text {rd }}\right.$ March to $16^{\text {th }}$ April, 2019). They found that the most significant reduction (30.3-48.5\%) was for $\mathrm{CO}$. A decrease in $\mathrm{NO}_{2}$ concentration was also observed, while $\mathrm{PM}_{10}$ levels only experienced a reduction in the first lockdown period. There was an increase in the concentration of $\mathrm{O}_{3}$ and this was associated with the decrease in $\mathrm{NO}_{2}$ levels.

This study aims to analyze the changes in air pollution levels for specific pollutants $\left(\mathrm{PM}, \mathrm{O}_{3}, \mathrm{NO}_{2}\right)$ during the COVID-19 lockdown period as compared to the ones obtained before the COVID-19 lockdown period of Cyprus using satellite data from the Giovanni website (https://giovanni.gsfc.nasa.gov/giovanni/).

\section{Material and Method}

\subsection{Study Area}

This study focused on Cyprus, the island located in the Eastern Basin of the Mediterranean Sea with coordinates between latitudes $34^{\circ}$ and $36^{\circ} \mathrm{N}$, and longitudes $32^{\circ}$ and $35^{\circ} \mathrm{E}$. The most and least polluted cities of Cyprus are Nicosia and Paphos, respectively. The island experiences a warm, Mediterranean climate which has long hot summers and mild, wet winters (Hadjinicolaou et al., 2011).

Some of the main industrial activities on the island include; agriculture, cement and gypsum, ship repair and refurbishment, textiles, light chemicals, metal products, wood, paper, stone and clay products, fisheries, shipping, construction, and food and beverage processing. In addition to vehicle and automobile emissions the emissions from industries, power plants, and houses are the main sources of pollution in Cyprus (Tsilingiridis et al., 2010).

As the first COVID-19 cases had been reported, the first lockdown in northern Cyprus started on the $15^{\text {th }}$ March and ended on the $4^{\text {th }}$ of May 2020 (Volkan \& Volkan, 2020), two weeks after the last patient was discharged from the hospital. During this period, there was a very limited movement of vehicles and persons. All schools, non-essential shops, restaurants, cafes, cinemas, gyms, playgrounds, and workplaces were closed down. People could only leave the house in case of an emergency. In addition, only factories that were involved in the production of essential goods and services were allowed to operate. Gradual reopening in businesses had started on the $5^{\text {th }}$ of May until the $15^{\text {th }}$ of May (Volkan \& Volkan, 2020). During this phase, people were asked to maintain social distance and use facemasks as compulsory measure. The crowds with more than 10 people in a closed area was also prohibited. In South Cyprus, the first restrictions started on the $11^{\text {th }}$ of March 2020, all the schools 
closed on March 13, and restrictions were eased after the 4th of May. On the $21^{\text {st }}$ of May, all schools reopened (Kolokotroni et al., 2021). For the whole island, lockdown phases and corresponding dates were determined to be used as given in Table 1 .

Table 1: Different lockdown periods for Cyprus.

\begin{tabular}{c|c|c}
\hline Phase & Lockdown Dates & Periods \\
\hline I & $1^{\text {st }}$ Jan $2020-14^{\text {th }}$ Mar 2020 & Pre-lockdown \\
\hline II & $15^{\text {th }}$ Mar $-4^{\text {th }}$ May 2020 & Total lockdown \\
\hline III & $5^{\text {th }}$ May $-30^{\text {th }}$ Jun 2020 & Partial lockdown \\
\hline
\end{tabular}

\subsection{Data}

Satellite data of $\mathrm{NO}_{2}, \mathrm{O}_{3}$, and particles were retrieved and analyzed in order to determine the effect of the lockdown on air quality in Cyprus. $\mathrm{NO}_{2}$ is emitted to the atmosphere principally by activities such as vehicles and other forms of transportation, combustion of fossil fuels in industries and power plants. $\mathrm{O}_{3}$ on its part can occur naturally and its concentration can be influenced by human activities (Apte et al., 2008) and formed as a secondary pollutant. It is found both in the stratosphere and troposphere. The interaction between UV light and molecular $\mathrm{O}_{2}$ leads to the formation of stratospheric ozone (the ozone layer) while the photochemical reactions between $\mathrm{VOC}$ and $\mathrm{NO}_{\mathrm{x}}$ will lead to the formation of ground-level $\mathrm{O}_{3}$ or tropospheric $\mathrm{O}_{3}$ (Goodman et al., 2009; Cakir and Sita, 2020). Finally, desert dust, VOC from vegetables, smoke from fires, and volcanic ash are the main natural sources of aerosols (Dutheil et al., 2020; Humbal et al., 2019). According to the studies of Querol et al. (2009) and Achilleos, et al. (2014), vehicular activities, sea salt sprays, transportation from European countries, dust re-suspension can be listed as the main anthropogenic and natural sources of particles in the region of Eastern Mediterranean.

In this study, satellite-derived data from the Giovanni website were used. $\mathrm{NO}_{2}$ and $\mathrm{O}_{3}$ data were obtained from NASA's OMI sensors, and AOD data, which was used to approximate PM (Stirnberg et al., 2018), was obtained from MODIS sensors. OMI is a Dutch and Finnish-built monitoring image spectrometer that is designated to distinguish ozone and other atmospheric gases. The instrument has a spectra region of 264-504 nm, a spectra resolution of $0.42-0.63 \mathrm{~nm}$, and a resolution of $0.125^{\circ} \times 0.125^{\circ}$ (Levelt et al., 2006). The MODIS instrument operates on both the Aqua and Terra spacecraft with a viewing swath width of 2330 $\mathrm{km}$ and views the whole earth's surface every 24 or 48 hours. The instrument acquires data at three spatial resolutions $(250,500$, and $1000 \mathrm{~m})$, and measures 36 spectral bands between 0.405 and 14,385 $\mu \mathrm{m}$ using its detectors (Gupta et al., 2016).

In this study, the product of $\mathrm{NO}_{2}$ Total Tropospheric Column (30\% Cloud Screened) (OMNO2d v003) with measuring unit of $\mathrm{cm}-2$ and spatial resolution of $0.25^{\circ}$ was used. For the ozone data the product of Total Ozone Column (TOMS-like) (OMTO3e v003) with DU as unit and $0.25^{\circ}$ as a spatial resolution; for particles the product of Combined Dark Target and Blue AOD at 0.55 micron for land and ocean: mean (MYDO8 D3 v6.1) with a spatial resolution of $1^{\circ}$ was used.

\subsection{Methodology}

The time series, area-average plot on Giovanni website was used to get daily data values for $\mathrm{NO}_{2}, \mathrm{O}_{3}$, and $\mathrm{AOD}$, for the period of $1^{\text {st }}$ January 2019 to $30^{\text {th }}$ June 2019 and also $1^{\text {st }}$ January 2020 to $30^{\text {th }}$ June 2020. These data were collected for the whole of Cyprus.

Excel, the Microsoft Office spreadsheet software program was used to;

- calculate monthly mean values of $\mathrm{AOD}$ and $\mathrm{NO}_{2}$ for the given periods for 2019 and 2020 ,

- calculate the percentage difference of the monthly mean values of 2019 and 2020 using Equation 1.

$\%$ difference $=\frac{\overline{\mathrm{X}}_{\mathrm{i}, 2020^{-}, \overline{\mathrm{X}}_{\mathrm{i}, 2019}}}{\overline{\mathrm{X}}_{\mathrm{i}, 2019}} \times 100$

where $\overline{\mathrm{X}}_{\mathrm{i}, 2019}$ and $\overline{\mathrm{X}}_{\mathrm{i}, 2020}$ represent monthly mean values of the $i$ th month in 2019 and 2020 respectively.

- $\quad$ apply t-test to deduce the significance of the difference in monthly mean values for the above-mentioned pollutants and periods for the entire island. 0.05 and 0.01 alpha levels were considered to evaluate the significance,

- calculate the mean and standard deviation of the AOD, $\mathrm{NO}_{2}$ and $\mathrm{O}_{3}$ values for the different periods (Table 1) (prelockdown, total lockdown, partial lockdown) during 2020 and calculate mean values for the same periods of 2019 ,

- calculate percentage difference of the mean values of three periods of 2020 compared to the same periods of 2019 Equation 1 was adapted for the calculations,

- $\quad$ apply t-test to show the significance of the difference of the periods means between the corresponding three periods of 2019 and 2020. 0.05 and 0.01 alpha levels were considered to evaluate the significance.

The negative data values (in the case of $\mathrm{NO}_{2}$ ) and all the filled values (this occurred when the measuring instrument could not detect the pollutant) were eliminated before starting the analysis and these data were not taken into consideration. On the other hand, in the study of Achillos et al (2014) the cases that AOD values greater than 0.3 together with Angstrom exponent (AE) less than 0.9 were used as an indicator of the desert dust particles presence. AE values were not been analyzed in this study, but similar to the other approach in Achillos et al. (2014), the days with AOD values higher than the 95th percentile value have been considered as days with high particles level that is associated with the dust storms. 95th percentile of the AOD values during the given periods in 2019 and 2020 was found as 0.61 and 0.44 respectively, that's why it was decided to neglect AOD values greater than 0.5 from both of the years to eliminate the effect of the possible dust transportation.

\section{Results and Discussion}

\subsection{Monthly mean differences}

Figure 1 illustrates the monthly mean AOD data from January to June for both 2019 and 2020 over Cyprus. There are increasing AOD values from January to April in both years, but the observed change from March to April in 2020 is less than that in 2019. This difference can be explained by decreased or even stopped vehicular activities during the lockdown. AOD values in February and March 2020 were observed to be higher than those of 2019. However, during April, May, and June 2020 the values were smaller than those of 2019 with the highest difference in June. Efforts have been made to eliminate the contribution of dust 
storms, but there are still high $(>0.3)$ AOD values that may lead to an increase in monthly average values.

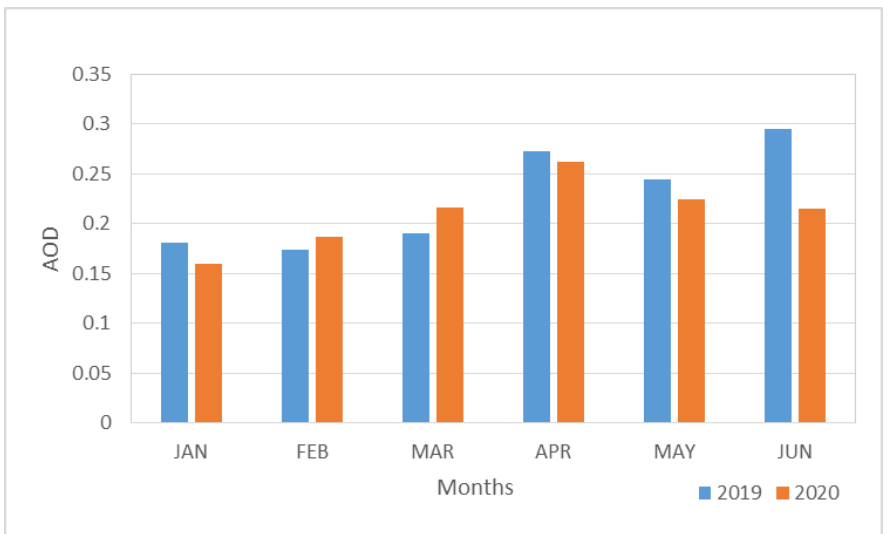

Figure 1. AOD monthly mean values for Cyprus (blue: 2019, orange:2020).

As seen in Figure 2, positive monthly percentage changes $(8 \%$ and $13 \%)$ in AOD values for February and March, respectively indicate an increase in PM concentrations as compared to 2019 values. According to the one-tailed t-test (for two-samples unequal variances) with 0.05 alpha level, all these positive and negative differences (except June) were found to be not significant $(\mathrm{p}>0.05)$. The highest and significant negative monthly mean difference between 2020 and 2019 was observed in June. The region was under the effect of dust storms during June 2019 (Kıbris Gazetesi, 2019a, Kıbrıs Gazetesi, 2019b). Therefore, high AOD values, less than 0.5 but greater than 0.3 , may have contributed to the high monthly mean AOD during June.

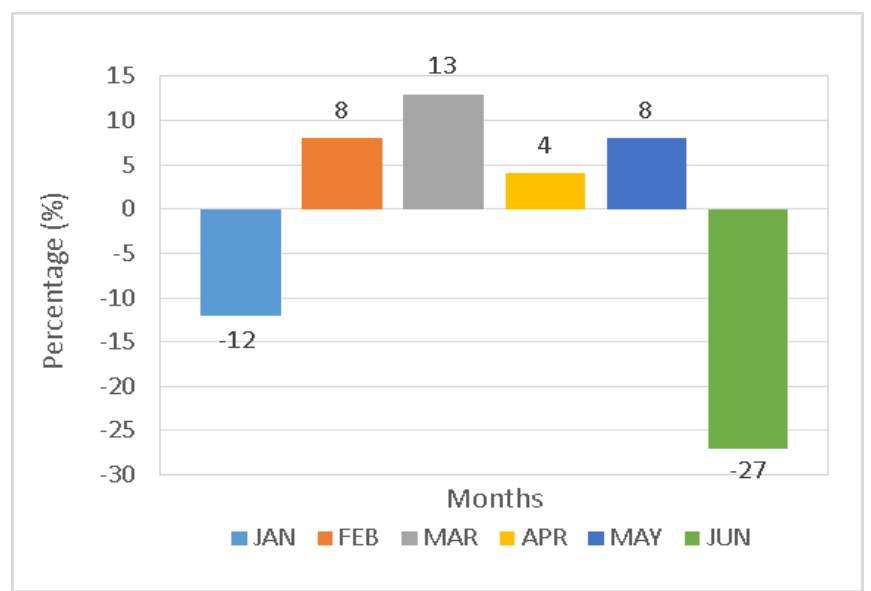

Figure 2. The percent differences between the 2020 and 2019 values in terms of monthly mean AOD data.

Monthly mean values of tropospheric $\mathrm{NO}_{2}$ for Cyprus, from January to June for both 2019 and 2020 were given in Figure 3. It is clear that monthly mean values in 2020 were lower than those of the corresponding months in 2019. The lowest values were observed in February and March in 2019. The road traffic decreased due to the lockdown in 2020, and the lowest monthly average values were detected in March and April. With the gradual re-opening in May and June, $\mathrm{NO}_{2}$ values increased to the same level as before the lockdown.

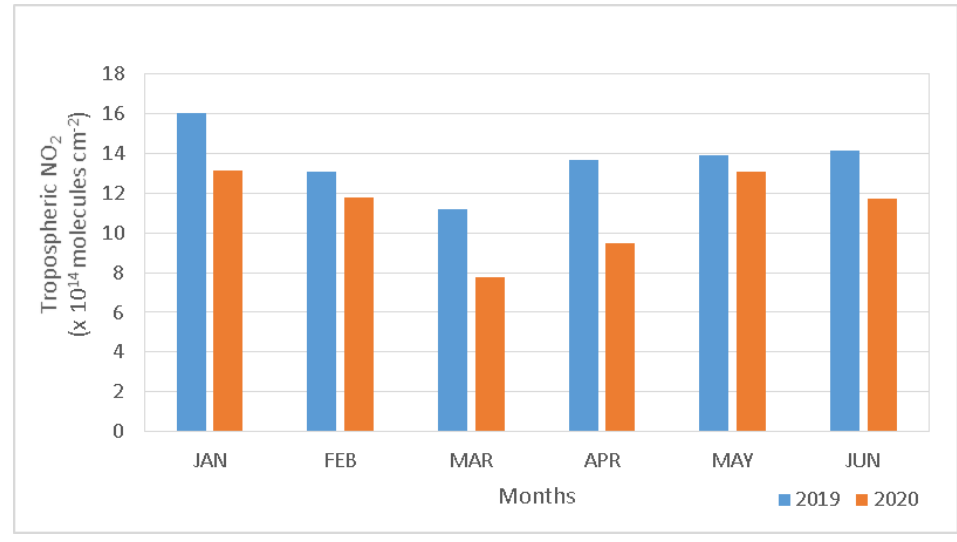

Figure 3. Monthly mean values of tropospheric $\mathrm{NO}_{2}$ for Cyprus (blue: 2019, orange:2020).

Percent differences between monthly mean values of $\mathrm{NO}_{2}$ in 2020 and 2019 (Figure 4) showed a significant decrease in March, April and June $(-31 \%,-31 \%,-17 \%)$. Decreased even stopped vehicular activities can explain these reductions during the March and April months. Percent changes in mean values with respect to 2019 were observed as negative values in January, February, and May also, but according to t-test with the 0.05 alpha level, the differences between mean values were not significant.

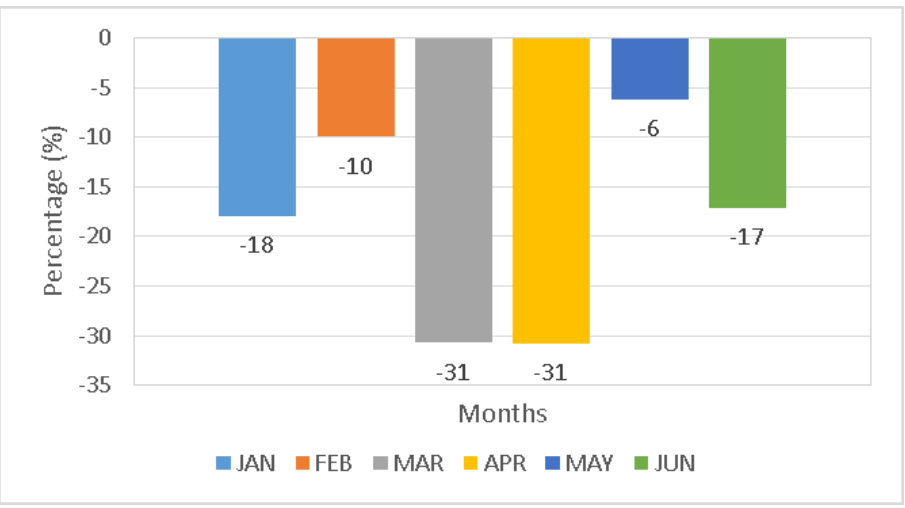

Figure 4. The percent differences between the 2020 and 2019 values in terms of monthly mean tropospheric $\mathrm{NO}_{2}$ values.

\subsection{Analysis for different periods}

The mean and standard deviation of $\mathrm{AOD}, \mathrm{NO}_{2}$, and Ozone values for the different periods (pre-lockdown, lockdown, partial lockdown) of the pandemic in 2020 were calculated. In order to determine the effect of the lockdown period on the air quality, mean and standard devation were obtained for the same periods of 2019, and percent change in mean values compared to 2019 was calculated. One-tailed t-test was applied at alpha levels of 0.05 and 0.10 , and the significance of the differences between mean values was evaluated in this section.

According to Table 2, the mean and standard deviation of the AOD values were the same for Period I (pre-lockdown) in both years of 2020 and 2019, and there is no change in mean values. During the lockdown period in 2020, AOD values showed an insignificant increase compared to the same period of 2019 while there was a significant decrease in values during the partial lockdown. Partial lockdown or gradual re-opening in some sectors had started on $5^{\text {th }}$ of May, 2020, and emissions from the human activities, especially from automobiles were expected to increase during this period and monthly values of $\mathrm{NO}_{2}$ presented these trends clearly, while AOD values have not increased during the 
May and June compared to the lockdown months. The highest and significant (at 0.05 alpha level) difference compared to the same period of 2019 in mean values of $\mathrm{NO}_{2}$ was observed during the lockdown period with a $32 \%$ reduction. A decrease in $\mathrm{NO}_{2}$ values was observed (9\%) also in partial lockdown compared to 2019 but it was found significant at 0.10 alpha level. Similar results were obtained by Zhang et al, (2020). They found 33\% reduction in $\mathrm{NO}_{2}$ at the continental level in East Asia, and 49\% reduction was obtained at the city scale in London.

Table 2. Statistical analysis of the pollutants during the different periods of Coronavirus Pandemic and same periods of 2019, in Cyprus.

\begin{tabular}{|c|c|c|c|c|}
\hline Pollutant & Period & $\begin{array}{c}2019 \\
\text { Mean } \\
\text { (std dev) }\end{array}$ & $\begin{array}{c}2020 \\
\text { Mean } \\
\text { (std dev) }\end{array}$ & $\begin{array}{c}\text { Relative } \\
\text { change } \\
(\%)\end{array}$ \\
\hline \multirow{3}{*}{ AOD } & I & $\begin{array}{c}0.18 \\
(0.08)\end{array}$ & $\begin{array}{c}0.18 \\
(0.08)\end{array}$ & 0 \\
\hline & II & $\begin{array}{c}0.24 \\
(0.11)\end{array}$ & $\begin{array}{c}0.25 \\
(0.10)\end{array}$ & 3 \\
\hline & III & $\begin{array}{c}0.27 \\
(0.11)\end{array}$ & $\begin{array}{c}0.22 \\
(0.09)\end{array}$ & $-20 *$ \\
\hline \multirow{3}{*}{$\mathrm{NO}_{2}$} & I & $\begin{array}{l}13.99 \\
(9.25)\end{array}$ & $\begin{array}{l}11.65 \\
(8.44)\end{array}$ & -17 \\
\hline & II & $\begin{array}{l}12.85 \\
(8.93)\end{array}$ & $\begin{array}{r}8.79 \\
(5.32)\end{array}$ & $-32 *$ \\
\hline & III & $\begin{array}{l}14.01 \\
(3.83)\end{array}$ & $\begin{array}{l}12.68 \\
(5.38)\end{array}$ & $-9 * *$ \\
\hline \multirow{3}{*}{$\mathrm{O}_{3}$} & I & $\begin{array}{l}311.34 \\
(34.40)\end{array}$ & $\begin{array}{l}335.05 \\
(24.60)\end{array}$ & $8^{*}$ \\
\hline & II & $\begin{array}{l}351.88 \\
(29.37)\end{array}$ & $\begin{array}{c}350.31 \\
(16.38)\end{array}$ & 0 \\
\hline & III & $\begin{array}{l}314.28 \\
(16.55)\end{array}$ & $\begin{array}{l}310.25 \\
(20.70)\end{array}$ & $-1 * *$ \\
\hline
\end{tabular}

* significant at 0.05 alpha level

**significant at 0.10 alpha level

Mean Ozone values showed a significant (at 0.05 alpha level) increase $(8 \%)$ in the pre-lockdown period compared to the same period of 2019, while the values were almost equal during the lockdown period of 2020 and the same period of 2019. It was observed that there is a significant (at 0.10 alpha level) decrease $(-1 \%)$ in mean values during period III (partial lockdown). Increasing $\mathrm{NO}_{2}$ values after lockdown might have an effect on the reduction in Ozone values because $\mathrm{NO}_{\mathrm{x}}$ has an important role for destroying the ozone in the troposphere.

According to Tobias et al. (2020) results, the most significant reduction ( -45 to $-51 \%$ ) was observed for $\mathrm{NO}_{2}$, mainly related to related to traffic emissions while $\mathrm{PM}_{10}$ had a lower decrease (-28 to $-31 \%$ ). Conversely, $\mathrm{O}_{3}$ values increased in levels compared to the values obtained before lockdown periods in Barcelona. The results of Tobias et al. (2020) are mostly in line with the results of this study.

\section{Conclusions and Recommendations}

In this study, the change in air quality in Cyprus during the lockdown periods of Coronoavirus pandemic was analysed. Monthly mean values of $\mathrm{AOD}$, tropospheric $\mathrm{NO}_{2}$ were obtained for the months from January to June of 2020 and 2019. Percent changes in monthly mean AOD values with respect to 2019 were calculated and the findings showed that changes in AOD were not significant. However, the analysis results applied for $\mathrm{NO}_{2}$ showed e-ISSN: 2148-2683 that there was a significant decrease in March, April and June values compared to values of the same months of 2019.

The period from January to June of 2020 was divided into 3 phases considering the dates of lockdown. Changes in the mean AOD, tropospheric $\mathrm{NO}_{2}$ and Ozone values during the periods before lockdown, lockdown, and partial lockdown were evaluated and compared to the values obtained during the same periods of 2019. According to the results, significant decrease in AOD values was only obtained for period III (partial lockdown). Because of the limited vehicular activities during the lockdown period, a significant reduction in $\mathrm{NO}_{2}$ values was observed.

Further studies can be conducted for Cyprus at the city-scale and analysis can be repeated to show how the air quality has changed during the lockdown period with respect to the 5 yearbaseline period.

\section{References}

Achilleos, S., Evans, J. S., Yiallouros, P. K., Kleanthous, S., Schwartz, J., Koutrakis, P. (2014). PM10 concentration levels at an urban and background site in Cyprus: the impact of urban sources and dust storms. Journal of Air\&Waste Management Association, 64(12), 1352-60.

Agbaire, P. O., \& Esiefarienrhe, E. (2009). Air Pollution tolerance indices (apti) of some plants around Otorogun Gas Plant in Delta State, Nigeria. Journal of Applied Sciences and Environmental Management, 13(1).

Apte, M. G., Buchanan, I. S. \& Mendell, M. J. (2008). Outdoor ozone and building-related symptoms in the BASE study. Indoor air, 18(2), 156-170.

Berman, J. D., \& Ebisu, K. (2020). Changes in US air pollution during the COVID-19 pandemic. Science of the Total Environment, 739, 139864.

Briz-Redón, Á., Belenguer-Sapiña, C., \& Serrano-Aroca, Á. (2021). Changes in air pollution during COVID-19 lockdown in Spain: a multi-city study. Journal of Environmental Sciences, 101, 16-26.

Bukhari, Q. \& Jameel, Y. (2020). Will Coronavirus Pandemic Diminish by Summer? SSRN Electronic Journal. doi: 10.2139/ssrn.3556998.

Cakir, S. \& Sita, M. (2020). Evaluating the performance of ANN in predicting the concentrations of ambient air pollutants in Nicosia, Atmospheric Pollution Research., 11(12), $2327-$ 2334.

Das, M., Das, A., Sarkar, R., Saha, S., \& Mandal, A. (2020). Examining the impact of lockdown (due to COVID-19) on ambient aerosols (PM 2.5): A study on Indo-Gangetic Plain (IGP) Cities, India. Stochastic Environmental Research and Risk Assessment, 1-17.

Dutheil, F., Baker, J. S., \& Navel, V. (2020). COVID-19 as a factor influencing air pollution?. Environmental pollution, 263, 114466.

Efe, B. (2021). Impact of COVID-19 Restrictions on Air Quality Levels on Samsun, Turkey. Environmental Science. Proceedings, 8(1), 6.

Gautam, S. (2020). COVID-19: Air pollution remains low as people stay at home. Air Quality, Atmosphere \& Health, 13, 853-857.

Goodman, J. E., Sax, S. N., Lange, S., \& Rhomberg, L. R. (2015). Are the elements of the proposed ozone National Ambient Air Quality Standards informed by the best available 
science?. Regulatory Toxicology and Pharmacology, 72(1), 134-140.

Gupta, P. Levy, R. C., Mattoo, S., Remer, L. A., Munchak, L. A. (2016). A surface reflectance scheme for retrieving aerosol optical depth over urban surfaces in MODIS Dark Target retrieval algorithm. Atmospheric Measurement Techniques, 9, pp. 3293-3308

Hadjinicolaou, P., Giannakopoulos, C., Zerefos, C., Lange, M. A., Pashiardis, S. \& Lelieveld, J. (2011). Mid-21st century climate and weather extremes in Cyprus as projected by six regional climate models. Regional Environmental Change, 11, 441-457.

Humbal, C., Joshi, S. K., Trivedi, U. K., \& Gautam, S. (2019). Evaluating the colonization and distribution of fungal and bacterial bio-aerosol in Rajkot, western India using multiproxy approach. Air Quality, Atmosphere \& Health, 12(6), 693-704.

Kerimray, A., Baimatova, N., Ibragimova, O. P., Bukenov, B., Kenessov, B., Plotitsyn, P., \& Karaca, F. (2020). Assessing air quality changes in large cities during COVID-19 lockdowns: The impacts of traffic-free urban conditions in Almaty, Kazakhstan. Science of the Total Environment, 730, 139179.

Kıbrıs Gazetesi, (2019a). Meteoroloji Dairesinden toz uyarısı. Kibris, https://www.kibrisgazetesi.com/kibris/meteorolojidairesinden-toz-uyarisi-3-h67646.html

Kıbris Gazetesi, (2019b). Toz zerrecikleri kirlilik yaratacak. Kibris, https://www.kibrisgazetesi.com/kibris/toz-zerrecikle ri-kirlilik-yaratacak-h69133.html).

Levelt, P. F., van den Oord, G. H., Dobber, M. R., Malkki, A., Visser, H., de Vries, J., Stammes, P., Lundell, J. O. V., \& Saari, H. (2006). The ozone monitoring instrument. IEEE Transactions on Geoscience and Remote Sensing, 44(5), 1093-1101.

Mahato, S., Pal, S., \& Ghosh, K. G. (2020). Effect of lockdown amid COVID-19 pandemic on air quality of the megacity Delhi, India. Science of the Total Environment, 730, 139086.

Marcos, A. (2011). Air: When breathing is threat. Why Newsletter, WHO Europe, Issue 4. Retrived from https://www.euro.who.int/_data/assets/pdf_file/0011/147656/WHY_Newsletter4. pdf.

Nakada, L. Y. K., \& Urban, R. C. (2020). COVID-19 pandemic: Impacts on the air quality during the partial lockdown in São Paulo state, Brazil. Science of the Total Environment, 730, 139087.

Patel, H., Talbot, N., Salmond, J., Dirks, K., Xie, S., \& Davy, P. (2020). Implications for air quality management of changes in air quality during lockdown in Auckland (New Zealand) in response to the 2020 SARS-CoV-2 epidemic. Science of the Total Environment, 746, 141129.

Querol, X., Pey, J., Pandolfi, M., Alastuey, A., Cusack, M., Pérez, N., Moreno, T., Viana, M., Mihalopoulos, N., Kallos, G., Kleanthous, S. (2009). African dust contributions to mean ambient PM10 mass-levels across the Mediterranean Basin. Atmospheric Environment, 43, 4266-4277.

Rai, P. K., Panda, L. L. S., Chutia, B. M., Singh, M. M. (2013). Comparative assessment of air pollution tolerance index (APTI) in the industrial (Rourkela) and non industrial area (Aizawl) of India: an eco-management approach. African Journal of Environmental Science and Technology, 7(10), 944-948.

Sicard, P., De Marco, A., Agathokleous, E., Feng, Z., Xu, X., Paoletti, E., Jaime, J., Rodriguez, D \& Calatayud, V. (2020).
Amplified ozone pollution in cities during the COVID-19 lockdown. Science of the Total Environment, 735, 139542.

Stirnberg R., Cermak J., Andersen H. (2018). An Analysis of Factors Influencing the Relationship between SatelliteDerived AOD and Ground-Level PM10. Remote Sensing, 10(9), 1353.

Şahin, Ü. A. (2020). The Effects of COVID-19 Measures on Air Pollutant Concentrations at Urban and Traffic Sites in Istanbul. Aerosol and Air Quality Research, 20, 1874-1885.

Tobías, A., Carnerero, C., Reche, C., Massagué, J., Via, M., Minguillón, M. C., Alastuey, A \& Querol, X. (2020). Changes in air quality during the lockdown in Barcelona (Spain) one month into the SARS-CoV-2 epidemic. Science of the Total Environment, 726, 138540.

Tosepu, R., Effendy, D. S., \& Ahmad, L. O. A. I. (2020). The first confirmed cases of COVID-19 in Indonesian citizens. Public Health of Indonesia, 6(2), 70-71.

Tsilingiridis, G., Sidiropoulos, C., Pentaliotis, A., Evripidou, C., Papastavros, C., Mesimeris, T., \& Papastavrou, M. (2010). A spatially allocated emissions inventory for Cyprus. Global Nest Journal, 12(1), 99-107.

Volkan, E., \& Volkan, E. (2020). Under the COVID-19 lockdown: Rapid review about the unique case of North Cyprus. Psychological Trauma. Theory, Research, Practice, and Policy, 12(5), 539.

Wang, L., Li, M., Yu, S., Chen, X., Li, Z., Zhang, Y., Jiang, L., Xia, Y., Li, J., Liu, W., Li, P., Lichtfouse, E., Rosenfeld, D \& Seinfeld, J. H. (2020). Unexpected rise of ozone in urban and rural areas, and sulfur dioxide in rural areas during the coronavirus city lockdown in Hangzhou, China: implications for air quality. Environmental Chemistry Letters, 18(5), 1713-1723.

Wang, Q., \& Su, M. (2020). A preliminary assessment of the impact of COVID-19 on environment-A case study of China. Science of the Total Environment, 728, 138915.

Zhang, Z., Arshad, A., Zhang, C., Hussain, S., \& Li, W. (2020). Unprecedented temporary reduction in global air pollution associated with COVID-19 forced confinement: A continental and city scale analysis. Remote Sensing, 12(15), 2420 .

Zhao, P., Tuygun, G. T., Li, B., Liu, J., Yuan, L., Luo, Y., Xiao, H \& Zhou, Y. (2019). The effect of environmental regulations on air quality: A long-term trend analysis of SO2 and NO2 in the largest urban agglomeration in southwest China. Atmospheric Pollution Research, 10(6), 2030-2039. 